\title{
AKTIVITAS TABIR SURYA EKSTRAK ETANOL HERBA KEROKOT (LYGODIUM MICROPHYLLUM)
}

\author{
Monalyta Panjaitan*, Adam M. Ramadhan, Dewi Rahmawati \\ Laboratorium Penelitian dan Pengembangan FARMAKA TROPIS, \\ Fakultas Farmasi Universitas Mulawarman, Samarinda, Kalimantan Timur \\ *Email : monalytapanjaitan@yahoo.com
}

\begin{abstract}
ABSTRAK
Herba Kerokot ( Lygodium microphyllum ) memiliki potensi beraktivitas sebagai tabir surya karena mengandung senyawa fenol dan flavonoid yang mampu menyerap sinar ultraviolet. Penelitian ini bertujuan untuk mengetahui kategori aktivitas tabir surya dari ektrak dan fraksi herba kerokot. Dilakukan ekstraksi herba kerokot lalu fraksinasi, kemudian ekstrak dan fraksi diukur menggunakan instrument spektofotometer pada panjang gelombang 292,5 -372,5 nm, Hasil pengukuran menunjukkan bahwa aktivitas tabir surya herba kerokot berdasarkan nilai presentase transmisi eritema( \% Te) dan presentase pigmentasi (\% Tp). berdasarkan presentase transmisi eritema aktvitas tabir surya herba kerokot termasuk dalam kategori fast tanning, proteksi ekstra dan suntan standar, sedangkan aktivitas tabir surya ekstrak herba kerokot berdasarkan presentase transmisi pigmentasi termasuk kategori sunblock dan potensi ekstra
\end{abstract}

Kata Kunci : Tabir surya, eritema, pigmentasi, kerokot, fraksinasi

\begin{abstract}
ABSTRAK
Herba Kerokot (Lygodium microphyllum) has the potential to act as a sunscreen because it contains phenol compounds and flavonoids that are able to absorb ultraviolet light. This study aims to determine the category of sunscreen activity from ektrak and hoker fractions. Execution of herbaceous kerokot then fraksinasi, then extract and fraction measured by instrument spectrophotometer at wavelength 292,5 -372,5 $\mathrm{nm}$. The result of measurement showed that herb sunscreen activity kerokot based on erythema transmission percentage value $(\%$ Te) and pigmentation percentage (\% Tp). Based on the percentage of the transmission of hermetically hazardous sunscreen erythema aktvitas included in the category of fast tanning, extra protection and standard suntan, while the sunscreen activity herb kerokot extract based on the percentage of pigmentation transmission including sunblock category and extra potential
\end{abstract}

Keyword: Sunscreen, erythema, pigmentation, kerokot, fractionation

Proceeding of the $5^{\text {th }}$ Mulawarman Pharmaceuticals Conferences, 


\section{PENDAHULUAN}

Indonesia adalah negara yang terletak di daerah tropis dengan paparan sinar matahari sepanjang musim. Sebagian penduduknya bekerja di luar ruangan sehingga mendapat banyak paparan sinar matahari bahkan pada saat matahari sedang terik. Radiasi sinar matahari dapat mempengaruhi kesehatan kulit semua individu ( Tahir, 2002). Dipermukaan bumi sinar matahari terdiri dari beberapa spektrum yaitu sinar infra merah (>760 nm), sinar tampak (400-760 nm), sinar ultra violet (UV) A (315-400 nm), sinar UVB (290-315 nm), dan sinar UVC (100-290 $\mathrm{nm})$ yang sangat berbahaya, memiliki energi yang sangat tinggi dan bersifat karsinogenik ( Wungkana, 2013).

Spektrum ultraviolet yang sampai ke bumi yaitu UV-A dengan panjang gelombang 320-400 nm menyebabkan pigmentasi dan UV-B dengan panjang gelombang 290-320 nm menyebabkan eritema. Sedangkan UV-C dengan panjang gelombang yang lebih kecil dari $290 \mathrm{~nm}$ tidak sampai ke bumi karena tersaring oleh ozon. Efek merugikan yang dapat ditimbulkan oleh radiasi ultraviolet pada kulit adalah terjadinya kerusakan epidermis yang biasa disebut dengan sengatan surya, pigmentasi, pengkerutan kulit, penuaan kulit dini, dan pada penyinaran yang lama dibawah terik matahari dapat mengakibatkan perubahan pada jaringan pengikat dalam lapisan korneum (Agustin, 2013). Spektrum pada panjang gelombang UV A dan UV B dapat menyebabkan kanker menurut National Toxicology program tahun 2005, Paparan sinar matahari UV menjadi penyebab 90\% terjadinya kanker melanoma malignant dan non melanoma ( Kanker sel basal (basal cell carcinoma / BCC dan kanker karsinoma sel squamous / SCC). Menurut Data National Cancer Institute kanker melanoma menjadi kasus yang meningkat terbanyak pada tahun 2012 ( Passantino dkk, 2013 ).

Senyawa tabir surya merupakan zat yang mengandung bahan pelindung kulit terhadap sinar matahari sehingga sinar UV tidak terpapar ke kulit (mencegah gangguan kulit karena radiasi sinar). Tabir surya dapat melindungi kulit dengan cara menyebarkan sinar matahari atau menyerap energi radiasi matahari yang mengenai kulit, sehingga energi radiasi tersebut tidak langsung mengenai kulit 
Flavonoid merupakan golongan fenol terbesar dan selain itu juga terdapat beberapa jenis fenol lainnya seperti fenol monosiklik sederhana, fenilpropanoid dan kuinon fenolik. Gugus aromatik yang dimiliki oleh senyawa fenol dapat menyerap kuat pada spectrum sinar UV. Salah satu manfaat dari flavonoid yaitu sebagai antioksidan. Antioksidan ialah molekul yang dengan mudah dapat memberikan elektronnya ke molekul radikal bebas sehingga dapat menstabilkan molekul radikal bebas dan mencegah proses oksidasi yang tidak diinginkan dalam sel (Wala dkk, 2015).

Tumbuhan kerokot (Lygodium microphylum) masih dianggap gulma oleh masyarakat Kalimantan Timur karena kemampuannya yang tumbuh cepat dan meluas ke segala arah dalam suatu areal lahan perkebunan sehingga mengganggu tanaman petani. Tumbuhan ini sukar dimusnahkan karena mudah tumbuh kembali dan merambat ke segala arah pada suatu area lahan sehingga dianggap sebagai gulma atau pengganggu tanaman perkebunan oleh petani. Tumbuhan ini di Kalimantan timur ditemukan di berbagai tempat dan tidak menjadi perhatian masyarakat bahkan dianggap sebagai tumbuhan pengganggu. Secara empirik pada masyarakat setempat, tumbuhan tersebut belum termanfaatkan pada aspek apapun kecuali sebagai obat luka ( Rijai, 2012).

Dari hasil penelitian Rijai didapatkan nilai $\mathrm{IC}_{50}$ fraksi etanol, fraksi $\mathrm{n}$ heksan, fraksi Etil asetat, fraksi n-butanol berturut-turut adalah 76,6 ppm; 195,28 ppm; 17,39 ppm dan 24,70 ppm. Sehingga ditinjau dari data tersebut Herba Kerokot memiliki aktivitas antioksidan yang cukup baik sehingga diharapkan dapat beraktivitas sebagai Tabir Surya. Hubungan aktivitas antioksidan dengan tabir surya sendiri yang mana Dalam Susanti (2013), bahwa senyawa yang memiliki aktivitas antioksidan dapat berpotensi sebagai sediaan tabir surya, beberapa golongan aktif antioksidan seperti flavonoid, tanin, dan beberapa turunan sinamat memiliki kemampuan perlindungan terhadap sinar UV. Sehingga hal ini yang mendasari dilakukannya pengujian tabir surya. 


\section{METODOLOGI PENELITIAN}

\section{Bahan}

Bahan yang digunakan : simplisia herba kerokot, aquadest, pelarut etanol, nbutanol, etil asetat dan n-heksan

\section{Peralatan}

Alat-alat yang digunakan: seperangkat alat gelas yang terdapat di laboratorium, rotary evaporator (BUCHI), spektrofotometri UV-Vis double beam (Dynamica Halo DB-20S), dan timbangan analitik

\section{PROSEDUR}

\section{Pengambilan Sampel}

Dilakukan pengambilan tanaman herba kerokot segar diperoleh di daerah Sangatta Kutai Timur. Sampel yang digunakan berupa simplisia herba kerokot.

\section{Ekstraksi dan Fraksinasi}

Simplisia herba kerokot sebanyak 900 gram dimasukan kedalam wadah maserasi. Sampel dimaserasi dengan pelarut etanol selama 3 hari. Maserasi ini diulangi dan filtrat yang terkumpul dipekatkan dengan rotary evaporator kemudian dilanjutkan di atas tangas air hingga diperoleh ekstrak kental etanol.

Ekstrak kental etanol ditambah aquadest, lalu difraksinasikan dengan pelarut n-heksan, etil asetat dan n-butanol sehingga diperoleh fraksi n-heksan, etil asetat dan n-butanol. Masing-masing fraksi kemudian dipekatkan dengan rotary evaporator dan didapatkan fraksi kental fraksi n-heksan, etil asetat dan n-butanol.

\section{Pengujian Aktivitas Tabir Surya}

Larutan sampel dibuat dalam etanol dengan konsentrasi 5 ppm hingga 300 ppm, masing-masing konsentrasi terdiri dari tiga replikasi dan diukur serapannya dengan menggunakan spektrofotometer UV-Vis pada panjang gelombang 292,5$372,5 \mathrm{~nm}$ dengan interval $5 \mathrm{~nm}$.

\section{Penentuan Profil Tabir Surya}

Data nilai \% Te dan \% Tp yang diperoleh dari hasil pengujian aktivitas tabir surya dikategorikan kedalam aktivitas tabir surya (Tabel 1). 
Tabel 1. Kategori Penilaian Aktivitas Tabir Surya

\begin{tabular}{ccc}
\hline Kategori & \% Te & \% Tp \\
\hline Sunblock & $<1$ & $3-40$ \\
Proteksi ekstra & $1-6$ & $42-86$ \\
Suntan standar & $6-12$ & $45-86$ \\
Fast tanning & $10-18$ & $45-86$ \\
\hline
\end{tabular}

\section{HASIL DAN PEMBAHASAN}

Tabir surya adalah zat yang mengandung bahan pelindung kulit terhadap sinar matahari sehingga sinar UV tidak terpapar ke kulit (mencegah gangguan kulit karena radiasi sinar). Tabir surya dapat melindungi kulit dengan cara menyebarkan sinar matahari atau menyerap energi radiasi matahari yang mengenai kulit, sehingga energi radiasi tersebut tidak langsung mengenai kulit. Uji Aktivitas tabir surya dimana dilakukan pengukuran pada panjang gelombang 273-392 nm menggunakan spektofotometri dengan etanol sebagai blanko. Kemudian nilai absorbansi dikonversikan menjadi nilai transmisi, nilai transmisi yang didapatkan dari setiap konsentrasi dilakukan perhitungan untuk mendapatkan nilai \% Te dan \% Tp

Persen transmisi eritema menunjukkan jumlah sinar matahari yang diteruskan setelah mengenai tabir surya sehingga dapat menyebabkan eritema kulit. Persen transmisi pigmentasi menunjukkan jumlah sinar yang diteruskan setelah mengenai suatu bahan tabir surya sehingga dapat menyebabkan pigmentasi kulit. Semakin kecil nilai \% transmisi eritema maupun pigmentasi diartikan bahwa potensi tabir surya untuk melindungi kulit lebih baik. Nilai \% Te dan \% Tp yang didapatkan kemudian dikategorikan termasuk sunblock, proteksi ekstra, suntan standar dan fast tanning.

Fast tanning adalah tabir surya yang dapat menggelapkan kulit secara cepat tanpa menimbulkan eritema dengan mampu memberikan transmisi penuh pada radiasi UV A untuk memberikan efek penggelapan yang maksimal.Aktivitas tabir surya ekstrak etanol sebagai fast tanning ditunjukkan pada \%Te pada konsentrasi 100 ppm, fraksi n-heksan di 200 ppm dan etil asetat di konsentrasi hingga 25 ppm Suntan standar adalah kategori penilaian aktivitas tabir surya dimana suatu bahan mampu mencegah sengatan sinar matahari dengan mengabsorbsi $95 \%$ atau lebih radiasi UV B. Kategori suntan standar menyerap sebagian besar sinar UV B dan 
menyerap sedikit sinar UV A sehingga dapat menyebabkan pigmentasi tanpa terjadinya eritema.

Tabel 2. Profil Tabir Surya Herba Kerokot

\begin{tabular}{|c|c|c|c|c|c|}
\hline Sampel & $\begin{array}{c}\text { Konsentrasi } \\
(\mathrm{ppm})\end{array}$ & $\% \mathrm{Te}$ & $\begin{array}{c}\text { Kategori } \\
\text { Penilaian } \\
\text { Tabir Surya }\end{array}$ & $\% \mathrm{Tp}$ & $\begin{array}{c}\text { Kategori } \\
\text { Penilaian } \\
\text { Tabir Surya }\end{array}$ \\
\hline \multirow{6}{*}{$\begin{array}{c}\text { Ekstrak } \\
\text { Kasar }\end{array}$} & 75 & 29.961 & - & 28.439 & Sunblock \\
\hline & 100 & 16,592 & Fast tanning & 15,272 & Sunblock \\
\hline & 125 & 10,330 & $\begin{array}{l}\text { Suntan } \\
\text { standar }\end{array}$ & 8,994 & Sunblock \\
\hline & 150 & 3,721 & $\begin{array}{l}\text { Proteksi } \\
\text { esktra }\end{array}$ & 2,673 & - \\
\hline & 175 & 2.622 & $\begin{array}{l}\text { Proteksi } \\
\text { esktra }\end{array}$ & 2,845 & - \\
\hline & 200 & 2.622 & $\begin{array}{l}\text { Proteksi } \\
\text { esktra }\end{array}$ & 1,899 & - \\
\hline \multirow{5}{*}{$\begin{array}{l}\text { Fraksi n- } \\
\text { heksan }\end{array}$} & 100 & 32,410 & - & 31,785 & Sunblock \\
\hline & 150 & 18,966 & - & 18,357 & Sunblock \\
\hline & 200 & 12,434 & Fast Tanning & 11.952 & Sunblock \\
\hline & 250 & 7,301 & $\begin{array}{l}\text { Suntan } \\
\text { standar }\end{array}$ & 6,786 & Sunblock \\
\hline & 300 & 5,745 & $\begin{array}{l}\text { Proteksi } \\
\text { ekstra }\end{array}$ & 5,258 & Sunblock \\
\hline \multirow{5}{*}{$\begin{array}{l}\text { Fraksi Etil } \\
\text { Asetat }\end{array}$} & 10 & 30,819 & - & 28,708 & Sunblock \\
\hline & 15 & 24,458 & - & 22,175 & Sunblock \\
\hline & 20 & 17,927 & Fast tanning & 15,558 & Sunblock \\
\hline & 25 & 14,878 & Fast tanning & 12,438 & Sunblock \\
\hline & 30 & 11,114 & $\begin{array}{l}\text { Suntan } \\
\text { Standar }\end{array}$ & 8,676 & Sunblock \\
\hline \multirow[t]{5}{*}{$\begin{array}{l}\text { Fraksi n- } \\
\text { butanol }\end{array}$} & 10 & 61,886 & - & 61,426 & $\begin{array}{l}\text { Suntan } \\
\text { standar }\end{array}$ \\
\hline & 20 & 56,083 & - & 55,652 & $\begin{array}{l}\text { Suntan } \\
\text { standar }\end{array}$ \\
\hline & 30 & 41,267 & - & 40,263 & $\begin{array}{l}\text { Proteksi } \\
\text { ekstra }\end{array}$ \\
\hline & 40 & 34,666 & - & 33.471 & $\begin{array}{l}\text { Proteksi } \\
\text { ekstra }\end{array}$ \\
\hline & 45 & 33.471 & - & 33,019 & $\begin{array}{l}\text { Proteksi } \\
\text { ekstra }\end{array}$ \\
\hline
\end{tabular}


Suntan standar mampu mencegah terjadinya eritema pada kulit normal atau jenis kulit yang tidak sensitif. Aktivitas Tabir surya ekstrak kasar herba kerokot herba kerokot sebagai suntan standar ditunjukkan \% Te terdapat pada konsentrasi 125 ppm , pada konsentrasi 250 ppm pada fraksi n-heksan dan pada konsentrasi 30 ppm pada fraksi etil asetat.

Proteksi ekstra adalah kemampuan ekstrak sebagai bahan tabir surya yang memberikan perlindungan terhadap eritema dengan mengabsorbsi kurang dari 85 \% radiasi sinar UV B serta mencegah terjadinya pigmentasi. Kategori proteksi ekstra tabir surya digunakan untuk melindungi jenis kulit yang sensitif. Aktivitas Tabir surya yang masuk dalam ketegori ini dinilai dari \% Te pada ekstrak kerokot berada pada konsentrasi 150 hingga 200 ppm, pada fraksi n-heksan mulai pada konsentrasi 300 ppm. Fraksi n-butanol termasuk kategori ini pada \% Tp berada pada konsentrasi 20 ppm

Sunblock merupakan kemampuan untuk memproteksi secara total kulit yang sangat sensitive terhadap sinar UV A dan UV B sehingga melindungi Kulit dari terjadinya eritema dan pigmentasi. Berdasarkan tabel dari \% Tp pada eksrak kasar berada pada konsentrasi hingga 125 ppm, fraksi n-heksan dimulai dari konsentrasi 100 hingga 300 ppm dan pada fraksi etil asetat mulai pada konsentrasi $10 \mathrm{ppm}$.

Secara umum ekstrak dan fraksi masuk dalam profil kategori tabir surya . Dikarenakan terdapat senyawa senyawa antioksidan yang juga berperan dalam aktivitas tabir surya. Beberapa golongan senyawa aktif antioksidan seperti flavonoid, tanin, antraquinon, sinamat telah dilaporkan memiliki kemampuan sebagai perlindungan terhadap sinar UV. Herba kerokot diketahui mengandung beberapa senyawa diantaranya turunan fenolik seperti flavonoid tanin yang berperan dalam meredam radiasi ultraviolet.

\section{KESIMPULAN}

Berdasarkan hasil penelitian yang dilakukan maka dapat disimpulkan setiap ekstrak dan fraksi termasuk dalam profil tabir surya. Aktivitas paling baik terdapat 
pada fraksi etil asetat dimana membutuhkan konsentrasi yang jauh lebih kecil dari ekstrak dan fraksi lainnya.

\section{DAFTAR PUSTAKA}

Agustin R., Yulida Oktadefitri., Henny Lucida. 2013. Formulasi Krim Tabir Surya Dari Kombinasi Etil P-metoksisinamat dengan Katekin. Prosiding Seminar Nasional Perkembangan Terkini Sains Farmasi dan Klinik.

Passantino, Lisa., Max Costa dan Mary Matsui. 2013. Highlights in Skin Cancer.

Rijai, Laode. 2012. Potensi Tumbuhan Kerokot (Lygodium microphyllum) Dalam Bidang Kefarmasian. Journal of Tropical Pharmacy Chemistry Vol 2 No 1

Wala, Marvin,. Edy Suryanto., Defny S. Wewengkang. 2015. Aktivitas Antioksidan dan Tabir Surya Fraksi dari Ekstrak Lamun (Syringodium Isoetifolium). Jurnal Ilmu Farmasi UNSRAT Vol 4 No.4.

Widyastuti., Rizqi Ikhwanda Fratama., Ade Seprialdi. 2015. Pengujian Aktivitas Antioksidan dan Tabir Surya Ekstrak Etanol Kulit Buah Naga Super Merah ( Hylocereus costaricensisz F.A.C. Weber) Britton \& Rose). Scientia Vol 5 No. 2

Wilkinson, J. B dan Moore, R. J., 1982, Harry's Cosmeticology (7 $7^{\text {th }}$ edition). Chemical Publishing Company. New York 